\title{
First record of leucism for the Toco Toucan, Ramphastos toco (Piciformes: Ramphastidae)
}

\author{
Eduardo Guimarães Santos ${ }^{a *}$ (D) and William Sousa De Paula \\ ${ }^{a}$ Laboratório de Planejamento para Conservação da Biodiversidade, Departamento de Zoologia, Instituto de Ciências \\ Biológicas, Universidade de Brasília, CP 04457, Campus Darcy Ribeiro, CEP 70919-970, Brasília, DF, Brasil

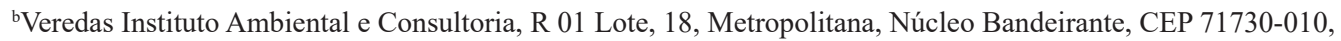 \\ Brasília, DF, Brasil \\ *egsantos1991@gmail.com
}

Received: January 12, 2019 - Accepted: July 18, 2019 - Distributed: August 31, 2020

(With 1 Figure)

Several factors can alter bird coloration patterns (Guay et al., 2012) and reports exist for different groups of birds (e.g. Urcola, 2011; Cadena-Ortiz et al., 2015). Regarding the different types of color alterations, leucism (Grouw, 2006) appears to be the most common type. Despite being the most common color pattern alteration in birds, no record was made for this species, the Toco Toucan (Ramphastos toco) (Muller, 1776).

The family Ramphastidae comprises about 50 species distributed in 5 genera, whose distribution is restricted to Central and South America. They have a long, narrow and brightly colored beak with either small or large serrations (Short and Horne, 2019). To our knowledge, to date, only three cases of leucism have been recorded for this family, being these species Andigena hypoglauca (Gould, 1833), Aulacorhynchus haematopygus (Gould, 1835) and Pteroglossus torquatus (Gmelin, 1788) (Cadena-Ortiz et al., 2015). Additionally, a distinct type of leukosis aberration, called schizochroism, occurs in Pteroglossus erythropygius (Gould, 1843) (Hosner and Lebbin, 2006).

Here, we report the first time a case of leucism in the Toco Toucan. The record was made on 04/04/2013 in an urban area of Brasília (area with predominance of grasses, roads and spaced trees), Brazil (1548'39.75" S $\left.47^{\circ} 51^{\prime} 59.37^{\prime} \mathrm{W}\right)$. The Toco Toucan has a distinct coloration, with the body being predominantly black, while the chat, throat and rump are white, and red undertail coverts (Sick, 1984). According to the spotting pattern of the individual observed (Figure 1), we can state that it exhibits partial leucism, because the pigmentation of the eye was normal and the black portion of its body had white spots, indicating that the pigment is produced, but is not properly deposited in the feathers (Grouw, 2006).

Wild birds with some type of alteration in their color patterns are common, and there has been an increase in the number of reports (Carbó-Ramírez et al., 2011). This increase in recordings may be related to the increased number of observers and the advent of the technology for image capture (Fuentes and González-Acuña, 2011). Additionally, this may also happen due to the increase in the number of aberrations in animal colorations, which may be related to the an expanded degree of isolation of the populations and endogamy (Bensch et al., 2000; Grouw,
2014), exposure to chemical substances (Ellegren et al., 1997), or radiation (Møller et al., 2013).

The detection of leucistic individuals is considered difficult because these animals are more visible to predators and, consequently, more easily preyed upon (Møller and Mousseau, 2001). In addition, such changes in coloration
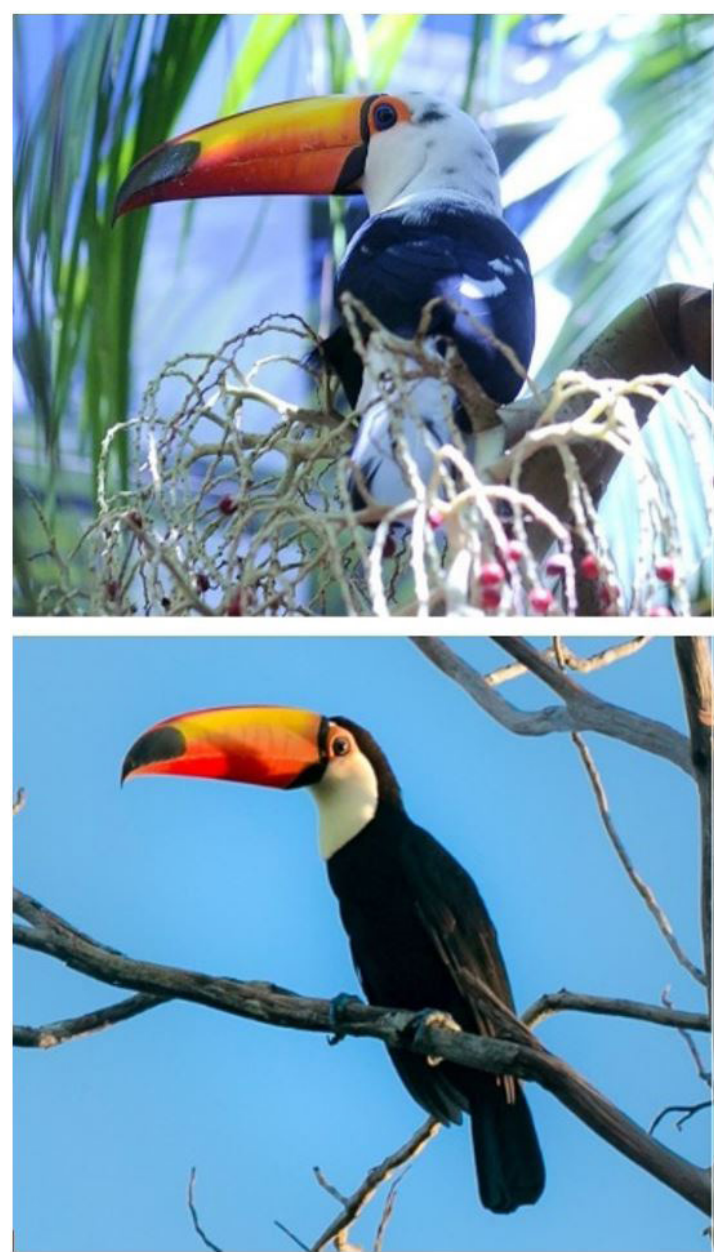

Figure 1. Partial leucism in Toco Toucan individual from an urban area of the Federal District, Brazil. Partial leucistic (Top) and Normal (Bottom), for comparison. 
may prevent reproduction for individuals (e.g. Blohowiak and Siegel, 1983; Parker et. al. 2003) or even hinder their regulation of body heat, considering that it is a large black bird (see Konter 2015). It is speculated that, due to an ever-increasing urban expansion (Seto et al., 2012), urban reports (such as in this case) may indicate a decrease in the predation pressure (Shochat et al., 2004), which in turn may lead to an increased survival rate of individuals with this type of alteration in their coloration (Gonçalves et al., 2008). Thus, the rarity of this event makes these records relevant.

\section{Acknowledgements}

We are grateful to Lorrayne Dias who made the registration and made the photo available for publication.

\section{References}

BENSCH, S., HANSSON, B., HASSELQUIST, D. and NIELSEN, B., 2000. Partial albinism in a semi-isolated population of Great Reed Warblers. Hereditas, vol. 133, no. 2, pp. 167-170. http://dx.doi. org/10.1111/j.1601-5223.2000.t01-1-00167.x. PMid:11338429.

BLOHOWIAK, C.C. and SIEGEL, P.B., 1983. Plumage phenotypes and mate preferences in Japanese quail 2. sexual imprinting. Behavioural processes, vol. 8, no. 3, pp. 255-275. http://dx.doi. org/10.1016/0376-6357(83)90016-5. PMid:24923714.

CADENA-ORTIZ, H., BAHAMONDE-VINUEZA, D., CISNEROS-HEREDIA, D. and BUITRÓN-JURADO, G., 2015. Alteraciones de coloración en el plumaje de aves silvestres del Ecuador. Avances En Ciencias e Ingenierías, vol. 7, no. 2, pp. B75-B90. http://dx.doi.org/10.18272/aci.v7i2.259.

CARBÓ-RAMÍREZ, P., ROMERO-GONZÁLEZ, P. and ZURIA, I., 2011. Primer reporte para México de coloración aberrante (leucismo parcial) en el cuitlacoche pico curvo (Toxostoma curviristre). Huitzil, vol. 12, no. 1, pp. 1-4.

ELlegren, H., LINDGREN, G., PRIMMER, C.R. and MØLLER, A.P., 1997. Fitness loss and germline mutations in barn swallows breeding in Chernobyl. Nature, vol. 389, no. 6651, pp. 593-596. http://dx.doi.org/10.1038/39303. PMid:9335497.

FUENTES, D. and GONZÁLEZ-ACUÑA, D., 2011. Aberraciones cromáticas del plumaje en aves: nuevos reportes en Chile. Boletin Chileno de Ornitologia, vol. 17, no. 2, pp. 113-121.

GONÇALVES, C.C., SILVA, E.A., LUCA, A.C., PONGILUPPI, T. and MOLINA, F.D.B., 2008. Record of a leucistic rufousbellied thrush Turdus rufiventris (Passeriformes, Turdidae) in São Paulo city, Southeastern Brazil. Revista Brasileira de Ornitologia = Brazilian Journal of Ornithology, vol. 16, no. 1, pp. 72-75.

GROUW, H.V., 2006. Not every white bird is an albino: sense and nonsense about colour aberrations in birds. Dutch Birding, vol. 28 , pp. $79-89$.
GROUW, H.V., 2014. Some black-and-white facts about the faeroese white-speckled Common Raven Corvus corax varius. Bulletin of the British Ornithologists 'Club, vol. 134, no. 1, pp. 4-13.

GUAY, P.J., POTVIN, D.A. and ROBINSON, R.W., 2012. Aberrations in plumage coloration in birds. Australian Field Ornithology, vol. 29, no. 1, pp. 23-30.

HOSNER, P.A. and LEBBIN, D.J., 2006. Observations of plumage pigment aberrations of birds in Ecuador, including Ramphastidae. Boletín SAO, vol. XVI, no. 01, pp. 30-43.

KONTER, A., 2015. Aberrant plumages in grebes Podicipedidae - An analysis of albinim, leucism, brown and other aberrations in all grebe species worldwide. Luxembourg: Musée National d'histoire Naturelle Luxembourg. Ferrantia, no. 72.

MØLLER, A.P. and MOUSSEAU, T.A., 2001. Albinism and phenotype of barn swallows (Hirundo Rustica) from chernobyl. Evolution; International Journal of Organic Evolution, vol. 55, no. 10, pp. 2097-2104. http://dx.doi.org/10.1111/j.0014-3820.2001. tb01324.x. PMid:11761068.

MØLLER, A.P., BONISOLI-ALQUATI, A. and MOUSSEAU, T.A., 2013. High frequency of albinism and tumours in freeliving birds around Chernobyl. Mutation Research/Genetic Toxicology and Environmental Mutagenesis, vol. 757, no. 1, pp. 52-59. http://dx.doi.org/10.1016/j.mrgentox.2013.04.019. PMid:23850808.

PARKER, T.H., STANSBERRY, B.M., BECKER, C.D. and GIPSON, P.S., 2003. Do melanin- or carotenoid-pigmented plumage ornaments signal condition and predict pairing success in the Kentucky Warbler? The Condor, vol. 105, no. 4, pp. 663671. http://dx.doi.org/10.1650/7335.

SETO, K.C., GUNERALP, B. and HUTYRA, L.R., 2012. Global forecasts of urban expansion to 2030 and direct impacts on biodiversity and carbon pools. Proceedings of the National Academy of Sciences of the United States of America, vol. 109, no. 40, pp. 16083-16088. http://dx.doi.org/10.1073/pnas.1211658109. PMid:22988086.

SHOCHAT, E., LERMAN, S.B., KATTI, M. and LEWIS, D.B., 2004. Linking optimal foraging behavior to bird community structure in an urban-desert landscape: field experiments with artificial food patches. American Naturalist, vol. 164, no. 2, pp. 232-243. http://dx.doi.org/10.1086/422222. PMid:15278846.

SHORT, L.L. and HORNE, J.F.M., 2019. Toucans (Ramphastidae). In: J. DEL HOYO, A. ELLIOTT, J. SARGATAL, D.A. CHRISTIE and E. JUANA, eds. Handbook of the birds of the world alive. Barcelona: Lynx Edicions.

SICK, H., 1984. Ornitologia brasileira. 3. ed. Brasília: Editora Universidade de Brasília, 828 p.

URCOLA, M.R., 2011. Aberraciones cromáticas en aves de la colección ornitológica del museo argentino de ciencias naturales "bernardino rivadavia". Revista Del Museo Argentino de Ciencias Naturales: Nueva Serie, vol. 13, no. 2, pp. 221-228. 